\title{
Estimation of Genetic Diversity in Mungbean [Vigna radiata (L.) Wilczek] Genotypes Grown in Gujarat
}

\author{
D.P. Joshi, L.D. Parmar, R.K. Meena, G.K. Chaudhary
}

10.18805/LR-4836

\begin{abstract}
Background: Genetically diverse parents give an increased chance of genetic recombination and superior expression of hybrid vigour. Mahalanobis $D^{2}$ statistics is an important tool for calculating the amount of genetic diversity in the populations and for assessing the relative contribution of various components to the total genetic divergence.

Methods: Thirty genotypes of mungbean [Vigna radiata (L.) Wilczek] were grown in a randomized block design with four replications at S.D.A.U., Gujarat during kharif, 2019 to study genetic diversity. By using Mahalanobis's D² statistics, all possible 435 pairs of thirty genotypes were computed for ten characters.

Result: $\mathrm{D}^{2}$ analysis indicated that material was genetically diverse. Twelve clusters were formed by dividing the genotypes. To become highly genetically diverse, the inter-cluster distance should be high (Distance between cluster XI and cluster IX; cluster XI and cluster $\mathrm{X}$ ), which can be used for hybridization programme. Cluster $\mathrm{X}$ followed by cluster I found appropriate for within group hybridization due to the presence of most heterogeneous genotypes indicating high intra-cluster value. Cluster data revealed that genotypes in cluster X, cluster VIII and cluster IV had desirable traits for yield improvement. These clusters could be directly selected for breeding programme. Contribution to total divergence was higher from number of branches per plant, pod length and 100 -seed weight.
\end{abstract}

Key words: Cluster, $D^{2}$ analysis, Genetic diversity, Mahalanobis $D^{2}$, Mungbean.

\section{INTRODUCTION}

In India, pulses occupy second place next to cereal in terms of vegetarian diet. High protein of pulses makes it rich man's vegetable and poor man's meat. WHO (World Health Organization) recommends to consume $80 \mathrm{~g}$ pulses for a person in a day, but per capita availability is only $42 \mathrm{~g} /$ person/day.

Mungbean is a diploid which has $2 n=2 x=22$ chromosomes and self-polinating nature. It is also known as greengram, goldengram, greenbean, greensoy, moong and mashbean. The center of origin for mungbean is not known exactly, but it might have originated in Hindustan and Central Asiatic region. In the world, mungbean cultivation is carried out in countries like India, Pakistan, Burma, Nepal, Bangladesh, Sri Lanka, Thailand, Indonesia, Philippines and Africa continent. Maharashtra, Gujarat andhra Pradesh, Tamil Nadu, Uttar Pradesh and Bihar are the Indian states which cultivate mungbean (Singh et al., 2010; Inbasekar, 2014; Kumar and Kumar, 2014). Mungbean has nutrition like 24 to $25 \%$ protein, $1.3 \%$ fat, $3.5 \%$ minerals, $4.1 \%$ fiber, $56 \%$ carbohydrate, $124 \mathrm{mg} / 100$ $\mathrm{g}$ calcium, $326 \mathrm{mg} / 100 \mathrm{~g}$ phosphorus, $7.3 \mathrm{mg} / 100 \mathrm{~g}$ iron, $334 \mathrm{kcal} / 100 \mathrm{~g}$ calorific value, 10 per cent moisture, $83 \mathrm{mg} /$ $100 \mathrm{~g}$ (Anonymous, 2017).

The major limiting factors for pulses production and productivity in our country are the non-availability of high yielding varieties which can tolerate environmental fluctuations to greater extent. Therefore, plant breeders want to study the genetic diversity in the varieties/germplasm. Genetically diverse parents generally produce high heterotic
Department of Genetics and Plant Breeding, C.P. College of Agriculture, Sardarkrushinagar Dantiwada Agricultural University, Sardarkrushinagar- 385 506, Gujarat, India.

Corresponding Author: D.P. Joshi, Department of Genetics and Plant Breeding, C.P. College of Agriculture, Sardarkrushinagar Dantiwada Agricultural University, Sardarkrushinagar-385 506, Gujarat, India. Email: joshidhruvp@gmail.com

How to cite this article: Joshi, D.P., Parmar, L.D., Meena, R.K. and Chaudhary, G.K. (2022). Estimation of Genetic Diversity in Mungbean [Vigna radiata (L.) Wilczek] Genotypes Grown in Gujarat. Legume Research. DOI: 10.18805/LR-4836.

Submitted: 16-11-2021 Accepted: 28-12-2021 Online: 14-02-2022

effects (Griffing and Lindston, 1954). For hybridization programme diverse genotype with broad genetic background should be selected as parents for bringing together higher frequency of desirable genes in a strain and to greater the possibility of generating broad spectrum of variability in segregating generation.

Selection of parents should be dependent on the number of important attributes collectively rather than individually for improving complex quantitative characters such as seed yield. Processes to measure divergence between population using Multivariate analysis are coefficient of racial likeness (Pearson, 1926), Discriminant function (Fisher, 1936), multiple regression (Hotelling, 1936) and $D^{2}$ statistics (Mahalanobis,1936). Among these, Mahalanobis (1936) $D^{2}$ statistics quantify the degree of divergence in populations at genetic level and assess the 
relative contribution of various components to the overall genetic divergence.

\section{MATERIALS AND METHODS}

Experiment season was kharif, 2019. Experiment site was Agronomy Instructional Farm, C.P. College of Agriculture, Sardarkrushinagar Dantiwada Agricultural University, Sardarkrushinagar, Gujarat, India. The experimental site represents typical sub-tropical climate with semi-arid and arid condition. Total thirty genotypes of greengram were selected from the Pulses Research Station, S.D.A.U., Sardarkrushinagar (Table 1). Randomized block design (RBD) with four replications were used to grow complete sets of 30 genotypes. Inter raw spacing was $45 \mathrm{~cm}$ and intraraw spacing was $10 \mathrm{~cm}$ as well as single plot of $3 \mathrm{~m}$ length was prepared for each genotype.

The observations were recorded as visual assessment and measurement on individual plants (five competitive randomly selected plants per genotype in each replication). Ten characters viz., days to flowering, days to maturity, plant height $(\mathrm{cm})$, number of branches per plant, number of pods per plant, number of seeds per pod, pod length $(\mathrm{cm}), 100-$ seed weight $(\mathrm{g})$, protein content $(\%)$ and seed yield per plant (g) were studied.

Genetic divergence was computed with the method of Mahanobis's D2 (Mahalanobis, 1936). Tocher's method was used to group the genotypes in different clusters (Rao, 1952). Average intracluster distance and average intercluster distance were obtained by using the method suggested by Singh and Chaudhary, 1977.

\section{RESULTS AND DISCUSSION}

ANOVA (analysis of variance) showed that differences in the genotypes were highly significant for all the traits, which indicated an ample scope to identify desirable genotypes to improve various traits.

Mahalanobis's $D^{2}$ statistics computed 435 pairs by using data of ten characters of 30 genotypes. The generalized distance (D) between two populations varies from 0.00 (intra cluster) to 19.456 (inter cluster) which indicates that there was a considerable diversity existed in the genotypes studied for the majority of the characters.

\section{Cluster composition}

Total twelve clusters were formed and their compositions are given in Table 2. Largest cluster was Cluster I with 10 genotypes followed by cluster II (7 genotypes), clusters III, $\mathrm{V}$ and $\mathrm{X}$ (each with 2 genotypes) and clusters IV, VI, VII, VIII, IX, XI and XII were with one genotype each.

$D^{2}$ analysis was done by many workers in this crop. Based on divergence Rahim et al. (2010) found 3 clusters from 26 genotypes, Sunil et al. (2011) found 8 clusters from 129 genotypes, Titumeer et al. (2014) found six clusters from 50 genotypes, Abbas et al. (2018) grouped 58 genotypes into four clusters and Mahalingam et al. (2018) grouped 445 genotypes into three clusters.

\section{Intra and inter-cluster distance}

The result of intra and inter-cluster distance (D) between all possible pairs of twelve clusters are shown in Table 3. Also, cluster diagram (Fig 1) showing the interrelationship among clusters. Intracluster divergence means the divergence between the genotypes of the same cluster. Intercluster divergence indicates the divergence between the genotypes of the different clusters.

Result showed that the intercluster distance (D) ranged from 5.721 to 19.456 . Minimum intercluster distance $(D=$ 5.721) was observed between clusters XI and XII. It indicated the presence of similarity in the genetic architecture of the genotypes of one cluster and another cluster. Maximum intercluster distance $(D=19.456)$ was observed between clusters IX and XI. It indicated the entire differences in the genetic architecture of genotypes of one cluster to another cluster.

Considering the highest intercluster distance, LM-584 (belonging to cluster $\mathrm{XI}$ ) was genetically divergent to LM-1 (belonging to cluster IX) and GM-4 and GAM-5 (belonging to cluster $\mathrm{X}$ ) which can be used for hybridization programme.

Table 1: Details of the mungbean genotypes and their origin/source. Name of genotypes Source Guj-1

PIMS-1

A-59-7

A-61-1

LAM-GG-127

GP-229-B

SML-68

M.GP-124-B

LM-141

MBC-5

LM-554

LM-578

No-223 (1)

LM-584

CM-512

LM-2

LM-1

LM-389

PS-10

LM-7

LM-359

LM-34

TT8E $\times 345$

LM-385

LM-350

LM-353

Chaklama-2

LM-309

GM-4

GAM-5 
Range of intra cluster distance (D) was 0.000 to 5.639 . Highest intracluster value $(D=5.639)$ was noticed for cluster $X$ followed by cluster I $(D=5.295)$ which indicated that genotypes of these clusters were most heterogeneous, probably have different genetic architecture and these clusters were the best for within group hybridization. Lowest intra cluster value $(D=4.199)$ was noticed for cluster III which proved that these accessions were passed through similar evolutionary factors than other cluster's genotypes. As the clusters IV, VI, VII, VIII, IX, XI and XII contains solitary genotype no intracluster distance has been worked out $(D=$ 0.000 each). Earlier researchers like Singh et al. (2009) found five mono selection clusters, Gokulakrishnan et al. (2012) and Panigrahi and Baisakh (2014) each found two clusters with solitary genotype, Gadakh et al. (2013) and Ahmad et al. (2016) each found three mono selection clusters.

The result revealed wide divergence (Fig 1) and substantial genetic diversity in the studied material for majority of the characters. Singh et al. (2009), Gokulakrishnan et al. (2012), Panigrahi and Baisakh (2014), Sunil et al. (2011), Titumeer et al. (2014) also found significant genetic diversity in this crop.

In heterosis breeding, inter-crossing between parents belonging to most divergent clusters are assumed to

Table 2: The distribution of thirty mungbean genotypes to various clusters on the basis of $D^{2}$ statistic.

\begin{tabular}{lcl}
\hline Clusters & Number of genotypes & Genotypes \\
\hline I & 10 & LM-141, LM-353, LM-350, Guj-1, SML-68, M.GP-124-B, LM-34, LM-385, LM-7, LM-554 \\
II & 7 & PIMS-1, A-59-7, LM-309, TT8E × 345, Chaklama-2, PS-10, LAM-GG-127 \\
III & 2 & LM-578, No-223(1) \\
IV & 1 & GP-229-B \\
V & 2 & A-61-1, LM-389 \\
VI & 1 & LM-359 \\
VII & 1 & LM-2 \\
VIII & 1 & MBC-5 \\
IX & 1 & LM-1 \\
X & 2 & GM-4, GAM-5 \\
XI & 1 & LM-584 \\
XII & 1 & CM-512 \\
\hline
\end{tabular}

Table 3: Average intra (bold) and inter-cluster values $\left(D^{2}\right.$ and $\left.D\right)\left(D=\sqrt{D^{2}}\right)$ for thirty genotypes of mungbean.

\begin{tabular}{|c|c|c|c|c|c|c|c|c|c|c|c|c|c|}
\hline Clusters & Values & I & II & III & IV & $\mathrm{V}$ & VI & VII & VIII & IX & $\mathrm{X}$ & $\mathrm{XI}$ & XII \\
\hline \multirow[t]{2}{*}{1} & $\mathrm{D}^{2}$ & 28.042 & 55.444 & 82.842 & 33.400 & 58.141 & 78.122 & 65.900 & 47.401 & 168.349 & 130.648 & 89.174 & 63.266 \\
\hline & $\mathrm{D}$ & 5.295 & 7.446 & 9.102 & 5.779 & 7.625 & 8.839 & 8.118 & 6.885 & 12.975 & 11.430 & 9.443 & 7.954 \\
\hline \multirow[t]{2}{*}{ II } & $\mathrm{D}^{2}$ & & 22.956 & 44.353 & 33.084 & 45.366 & 33.023 & 40.106 & 114.522 & 68.631 & 105.213 & 176.177 & 104.321 \\
\hline & $D$ & & 4.791 & 6.660 & 5.752 & 6.735 & 5.747 & 6.333 & 10.701 & 8.284 & 10.257 & 13.273 & 10.214 \\
\hline \multirow[t]{2}{*}{ III } & $\mathrm{D}^{2}$ & & & 17.630 & 68.497 & 98.770 & 50.783 & 83.144 & 169.398 & 53.137 & 144.267 & 229.991 & 181.053 \\
\hline & $D$ & & & 4.199 & 8.276 & 9.938 & 7.126 & 9.118 & 13.015 & 7.290 & 12.011 & 15.165 & 13.456 \\
\hline \multirow[t]{2}{*}{ IV } & $D^{2}$ & & & & 0.000 & 43.551 & 42.230 & 39.836 & 52.422 & 123.359 & 93.794 & 129.923 & 65.220 \\
\hline & $D$ & & & & 0.000 & 6.599 & 6.498 & 6.312 & 7.240 & 11.107 & 9.685 & 11.398 & 8.076 \\
\hline \multirow[t]{2}{*}{ V } & $D^{2}$ & & & & & 19.266 & 87.265 & 33.010 & 81.611 & 118.709 & 80.139 & 129.882 & 54.718 \\
\hline & $\mathrm{D}$ & & & & & 4.389 & 9.342 & 5.745 & 9.034 & 10.895 & 8.952 & 11.397 & 7.397 \\
\hline \multirow[t]{2}{*}{ VI } & $D^{2}$ & & & & & & 0.000 & 56.689 & 146.427 & 74.021 & 161.340 & 234.687 & 158.695 \\
\hline & $\mathrm{D}$ & & & & & & 0.000 & 7.529 & 12.101 & 8.604 & 12.702 & 15.319 & 12.597 \\
\hline \multirow[t]{2}{*}{ VII } & $\mathrm{D}^{2}$ & & & & & & & 0.000 & 110.385 & 79.564 & 50.460 & 215.148 & 118.622 \\
\hline & $D$ & & & & & & & 0.000 & 10.506 & 8.920 & 7.104 & 14.668 & 10.891 \\
\hline \multirow[t]{2}{*}{ VIII } & $\mathrm{D}^{2}$ & & & & & & & & 0.000 & 292.722 & 160.164 & 76.075 & 52.051 \\
\hline & $\mathrm{D}$ & & & & & & & & 0.000 & 17.109 & 12.656 & 8.722 & 7.215 \\
\hline \multirow[t]{2}{*}{ IX } & $D^{2}$ & & & & & & & & & 0.000 & 121.941 & 378.521 & 268.078 \\
\hline & $\mathrm{D}$ & & & & & & & & & 0.000 & 11.043 & 19.456 & 16.373 \\
\hline \multirow[t]{2}{*}{$x$} & $D^{2}$ & & & & & & & & & & 31.800 & 295.904 & 180.682 \\
\hline & $D$ & & & & & & & & & & 5.639 & 17.202 & 13.442 \\
\hline \multirow[t]{2}{*}{$X I$} & $D^{2}$ & & & & & & & & & & & 0.000 & 32.735 \\
\hline & $D$ & & & & & & & & & & & 0.000 & 5.721 \\
\hline \multirow[t]{2}{*}{ XII } & $\mathrm{D}^{2}$ & & & & & & & & & & & & 0.000 \\
\hline & $D$ & & & & & & & & & & & & 0.000 \\
\hline
\end{tabular}


produce maximum amount of heterosis. However, to improve a specific character in breeding programme, it is advised to choose the donor from an appropriate cluster.

\section{Cluster means of various quantitative traits}

Cluster means of ten traits of thirty genotypes are shown in Table 4. Cluster data showed that genotypes in cluster $X$ had medium pod (8.22), maximum 100-seed weight (4.37), maximum protein content (21.88) and maximum seed yield per plant (5.19); genotypes in cluster VIII had maximum number of branches per plant (1.00) and more number of pods per plant (20.36); genotypes in cluster XI had maximum number of branches per plant (1.00), late flowering (55.75), lowest number of pods per plant (10.35) and minimum seed yield (2.10); genotypes in cluster XII were late maturing (84.75) and tallest (98.90); genotypes in cluster III were early maturing (59.38), medium heighted (53.85) and with minimum number of seeds per pod (10.09); genotypes in cluster IV had the highest mean value for number of seeds per pod (12.08); genotypes in cluster $\mathrm{V}$ had the lowest protein content (20.14); genotypes in cluster VI were short podded (6.46) and with lowest 100-seed weight (2.56); genotypes in cluster IX were early flowering (38.75) and with lowest number of branches per plant $(0.00)$.

These results indicated that cluster $X$ which contained the popular check varieties GM-4 and GAM-5 with most desirable characters, could be directly selected and utilized

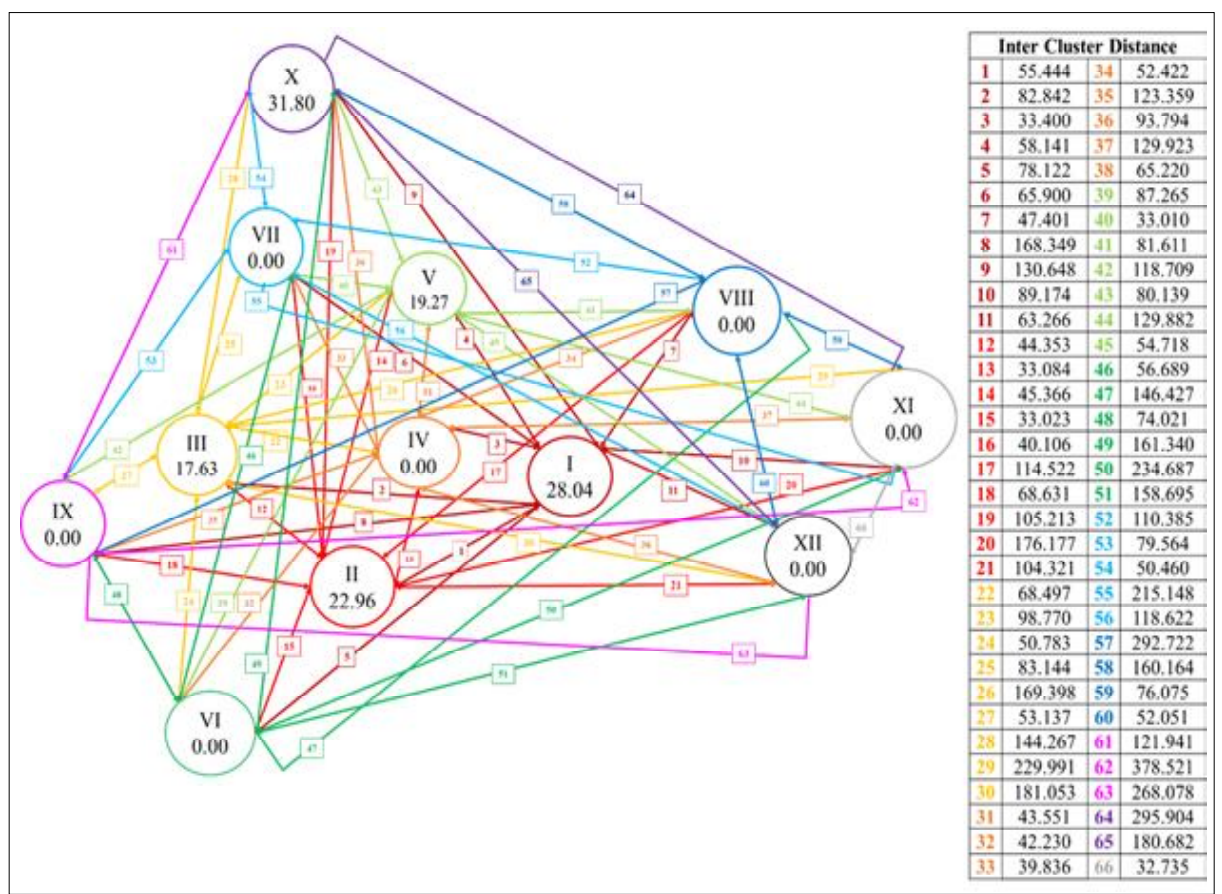

Fig 1: Cluster diagram indicating interrelationship between twelve clusters using $D^{2}$ analysis ( $D^{2}$ value) (not to scale).

Table 4: Cluster means for ten traits in thirty genotypes of mungbean.

\begin{tabular}{lcccccccccc}
\hline Clusters & $\begin{array}{c}\text { Days } \\
\text { to } \\
\text { flowering }\end{array}$ & $\begin{array}{c}\text { Days } \\
\text { to } \\
\text { maturity }\end{array}$ & $\begin{array}{c}\text { Plant } \\
\text { height } \\
(\mathrm{cm})\end{array}$ & $\begin{array}{c}\text { Number } \\
\text { of branches } \\
\text { per plant }\end{array}$ & $\begin{array}{c}\text { Number } \\
\text { of pods } \\
\text { per plant }\end{array}$ & $\begin{array}{c}\text { Number } \\
\text { of seeds } \\
\text { per pod }\end{array}$ & $\begin{array}{c}\text { Pod } \\
\text { length } \\
\text { (cm) }\end{array}$ & $\begin{array}{c}\text { 100-seed } \\
\text { weight } \\
(\mathrm{g})\end{array}$ & $\begin{array}{c}\text { Protein } \\
\text { content } \\
(\%)\end{array}$ & $\begin{array}{c}\text { Seed yield } \\
\text { per plant } \\
(\mathrm{g})\end{array}$ \\
\hline I & 45.15 & 72.80 & 74.04 & 0.72 & 15.72 & 10.59 & 6.90 & 2.90 & 21.84 & 3.33 \\
II & 44.54 & 70.14 & 77.81 & 0.37 & 15.26 & 10.19 & 6.78 & 3.10 & 21.69 & 3.50 \\
III & 39.25 & 59.38 & 53.85 & 0.40 & 11.50 & 10.09 & 6.60 & 3.08 & 21.30 & 2.80 \\
IV & 48.75 & 73.75 & 68.40 & 0.50 & 15.30 & 12.08 & 6.90 & 3.16 & 20.70 & 3.95 \\
V & 46.63 & 74.38 & 89.93 & 0.53 & 15.06 & 10.26 & 7.33 & 3.40 & 20.14 & 3.65 \\
VI & 45.00 & 73.25 & 61.20 & 0.20 & 17.18 & 11.04 & 6.46 & 2.56 & 20.76 & 3.00 \\
VII & 42.50 & 74.00 & 75.75 & 0.40 & 17.39 & 10.89 & 7.66 & 3.28 & 20.67 & 4.70 \\
VIII & 47.25 & 75.75 & 77.50 & 1.00 & 20.36 & 10.51 & 6.60 & 3.12 & 21.14 & 4.27 \\
IX & 38.75 & 60.00 & 64.45 & 0.00 & 11.56 & 10.50 & 7.44 & 3.48 & 21.09 & 2.88 \\
X & 41.00 & 66.25 & 74.25 & 0.50 & 16.07 & 10.71 & 8.22 & 4.37 & 21.88 & 5.19 \\
XI & 55.75 & 80.25 & 93.30 & 1.00 & 10.35 & 10.96 & 6.75 & 2.65 & 21.03 & 2.10 \\
XII & 54.50 & 84.75 & 98.90 & 0.75 & 11.94 & 11.25 & 6.92 & 3.11 & 20.38 & 3.22 \\
\hline
\end{tabular}


Table 5: Per cent contribution of various traits to the total genetic divergence.

\begin{tabular}{lcc}
\hline Characters & $\begin{array}{c}\text { Number of times } \\
\text { characters ranked first }\end{array}$ & $\begin{array}{c}\text { Per cent } \\
\text { contribution }\end{array}$ \\
\hline Days to flowering & 6 & 1.38 \\
Days to maturity & 20 & 4.60 \\
Plant height (cm) & 26 & 5.98 \\
Number of branches per plant & 208 & 47.81 \\
Number of pods per plant & 14 & 3.22 \\
Number of seeds per pod & 7 & 1.61 \\
Pod length (cm) & 77 & 17.70 \\
l00-seed weight (g) & 55 & 12.64 \\
Protein content (\%) & 21 & 4.83 \\
Seed yield per plant (g) & 1 & 0.23 \\
Total & 435 & 100.00 \\
\hline
\end{tabular}

for breeding programme. Also, it is advised to cross between genotypes from most distance clusters with high mean performance to achieve desirable transgressive segregants.

\section{Per cent contribution of different traits towards divergence}

The selection of parents mostly depends on contribution of various traits towards divergence. The component of $D^{2} s$ (because of each character variable) were ranked in descending order of magnitude (highest value has given rank I). The component of $D^{2}$ is the squares of difference in the transformed uncorrelated mean values related to that character variable. The total of these ranks in all possible 435 combinations provides indirect knowledge of the order of priority in the forms of percentage contribution of the trait to the total divergence. This per cent contribution of various traits towards divergence is shown in Table 5 .

Number of branches per plant was the greatest contributor to the total divergence i.e., 208 times (47.81\%) out of 435 . The next larger contributors are pod length (77 cases or $17.70 \%$ ) followed by 100 -seed weight ( 55 cases or $12.64 \%$ ), plant height (26 cases or $5.98 \%$ ), protein content ( 21 cases or $4.83 \%$ ), days to maturity (20 cases or $4.60 \%$ ), number of pods per plant (14 cases or $3.22 \%$ ), number of seeds per pod (7 cases or1.61\%), days to flowering (6 cases or $1.38 \%$ ) and seed yield per plant (1 cases or $0.23 \%$ ). Similar trend noticed by Singh et al. (2009) and Rekha et al. (2015) for 100-seed weight.

\section{CONCLUSION}

Genetic diversity using $D^{2}$ analysis indicated that material studied was genetically diverse. The genotypes were partitioned into twelve clusters. Considering the highest inter-cluster distance, LM-584 (belonging to cluster $\mathrm{XI}$ ) was genetically divergent with LM-1 (belonging to cluster IX) and with GM-4 and GAM-5 (belonging to cluster X) which can be used for hybridization programme. Intra-cluster value was highest for cluster $X$ followed by cluster I which indicated that genotypes of these clusters were most heterogeneous and these clusters were the best for within group hybridization.

Cluster data revealed that genotypes in cluster X (GM-4 and GAM-5) had medium pod $(8.22 \mathrm{~cm})$, maximum 100 -seedweight $(4.37 \mathrm{~g})$, maximum protein content (21.88 per cent) and maximum seed yield per plant $(5.19 \mathrm{~g})$; genotypes in cluster VIII (MBC-5) had maximum number of branches per plant (1.00) and more number of pods per plant (20.36); cluster IV (GP-229-B) had the highest mean value for number of seeds per pod (12.08). These clusters could be directly selected and utilized for breeding programme. Traits like number of branches per plant, pod length and 100-seed weight were found greater contributors to total morphological divergence.

\section{ACKNOWLEDGEMENT}

Special thanks to Pulse Research Station for providing material and C. P. College of Agriculture along with Directorate of Research, S.D.A.U., Sardarkrushinagar for providing research facility.

Conflict of interest: None.

\section{REFERENCES}

Abbas, G., Asghar, M.J., Rizwan, M., Akram, M., Hussain, J. and Ahmad, F. (2018). Genetic analysis of yield and yield components for the improvement of mungbean germplasm. Pakistan Journal of Agricultural Research. 31(2): 158-165.

Ahmad, A., Razvi, S.M., Rather, M.A., Ahmad, A., Zaffar, G., Ganie, S.A., Mir, M.R. and Rehman, H.K. (2016). Estimation of genetic divergence in mungbean (Vigna radiata L.) under temperate ecology of Kashmir. Research and Reviews: Journal of Botanical Sciences. 5(1): 29-33.

Anonymous (2017). Mung bean production technology. Ministry of Agriculture and Farmers Welfare, Department of Agriculture Co-operation and Farmers Welfare, Directorate of Pulses Development, Madhya Pradesh, India. Director of Directorate of Pulses Development. p. 3.

Fisher, R.A. (1936). The use of multiple measurements in taxonomic problems. Annals of Eugenics. 7(2): 179-188.

Gadakh, S.S., Dethe, A.M., Kathale, M.N. and Kahate, N.S. (2013). Genetic diversity for yield and its component traits in greengram [Vigna radiata (L.) Wilczek]. Journal of Crop and Weed. 9(1): 106-109.

Gokulakrishnan, J., Kumar, B.S. and Prakash, M. (2012). Studies on genetic diversity in mungbean studies on genetic diversity in mungbean (Vigna radiata L.). Legume Research. 35(1): 50-52.

Griffing, B. and Lindston, E.W. (1954). A study of combining abilities of corn inbreds having varying proportions of corn-belt and non-corn belt germplasm. Agronomy Journal. 46(12): 545-552.

Hotelling, H. (1936). Relation between two sets of varieties. Biometrika. 28: 321-377.

Inbasekar, K. (2014). Pulses Production in India: Challenges and Strategies. Economic Affairs. 59(3): 403-414. 
Kumar, S. and Kumar, R. (2014). Genetic improvement in mungbean [Vigna radiata (L.) Wilczek] for yield, nutrition and resistance to stresses- A review. International Journal of Tropical Agriculture. 32(3-4): 683-687.

Mahalanobis, P.C. (1936). On the Generalized Distance in Statistic. Proceedings of National Academy of Sciences in India. 2: $45-55$.

Mahalingam, A., Manivannan, A., Ragul, S. and Narayanan, S.L. (2018). Genetic divergence among greengram [Vigna radiata (L.) Wilczek] germplasm collections. Electronic Journal of Plant Breeding. 9(1): 350-354.

Panigrahi, K.K. and Baisakh, B. (2014). Genetic diversity assessment for yield contributing characters of greengram [Vigna radiata (L.) Wilczek]. Environment and Ecology. 32(1a): 294-297.

Pearson, K. (1926). On the coefficient of racial likeness. Biometrika. 18(1-2). p. 105.

Rahim, M.A., Mia, A.A., Mahmud, F., Zeba, N. and Afrin, K.S. (2010). Genetic variability, character association and genetic divergence in mungbean [Vigna radiata (L.) Wilczek]. Plant Omics Journal. 3(1): 1-6.

Rao, C.R. (1952). Advanced Statistical Methods in Biometric Research. John Willy and Sons Inc., New York. p. 390.
Rekha, K.S., Reddy, D.M., Reddy, K.H.P., Rajeswari, V.R., Reddy, B.R.K. and Reddy, B.R. (2015). Genetic diversity studies under moisture stress condition in mungbean [Vigna radiata (L.) Wilczek]. Electronic Journal of Plant Breeding. 6(1): 225-232.

Singh, B.B., Dixit, G.P. and Katiyar, P.K. (2010). Vigna Research in India (25 Years Research Achievements). All India Coordinated Research Project on MULLaRP, Indian Institute of Pulses Research (IIPR), Kanpur, India. pp. 1-155.

Singh, R.K. and Chaudhary, B.D. (1977). Biometrical Methods in Quantitative Genetic Analysis. Kalyani Publishers, New Delhi. pp. 215-218.

Singh, S.K., Singh, I.P., Singh B.B. and Singh O. (2009). Genetic divergence in mungbean [Vigna radiata (L.) Wilczek]. Legume Research. 32(2): 98-102.

Sunil, S.P., Kumar, K.M.H., Savithramma, D.L. and Dayamani, K.J. (2011). Studies on genetic variation and association analysis of yield and its attributing traits in greengram [Vigna radiata (L.) Wilczek]. Mysore Journal of Agricultural Science. 45(1): 101-106.

Titumeer, S.M., Rahim, M.A. and Zeba, N. (2014). Genetic variability, character association and genetic divergence in mungbean [Vigna radiate (L.) Wilczek]. Agronomski glasnik. 76(6): 305-326. 